\title{
THE
}

$4-2-2014$

\section{Ocean Surfing as a Novel Physiotherapy Environment: A Commentary}

\author{
Linda S. Lamont \\ University of Rhode Island, lamont@uri.edu \\ Cortney Armitano \\ University of Rhode Island \\ Emily Clapham \\ University of Rhode Island, eclapham@uri.edu
}

Follow this and additional works at: https://digitalcommons.uri.edu/kinesiology_facpubs

Creative Commons License

(c) (i)

This work is licensed under a Creative Commons Attribution 3.0 License.

\section{Citation/Publisher Attribution}

Lamont LS, Armitano C, Clapham E (2014) Ocean Surfing as a Novel Physiotherapy Environment: A Commentary. J Nov Physiother 4:e133 doi: 10.4172/2165-7025.1000e133

Available at: http://dx.doi.org/10.4172/2165-7025.1000e133

This Editorial is brought to you for free and open access by the Kinesiology at DigitalCommons@URI. It has been accepted for inclusion in Kinesiology Faculty Publications by an authorized administrator of DigitalCommons@URI. For more information, please contact digitalcommons-group@uri.edu. 


\title{
Ocean Surfing as a Novel Physiotherapy Environment: A Commentary
}

\author{
Linda S Lamont ${ }^{1}$, Cortney Armitano ${ }^{1,2}$ and Emily Clapham ${ }^{1}$ \\ ${ }^{1}$ Department of Kinesiology, College of Human Science and Services, University of Rhode Island, Kingston, USA \\ ${ }^{2}$ Veterans Administration Medical Center, Providence, Rhode Island, USA
}

Aquatic exercise for both fitness and rehabilitation are presently being offered to individuals of various special populations [1]. Pool programs offer physical activity and educational programming that can be particularly helpful for children with disabilities. The physiologic, psychologic, and social benefits of aquatic exercise are often found to be more pronounced in these children [2]. One reason aquatic exercise is of value is that the buoyancy provided allows the individual with landbased activity limitations to function in an independent fashion in the water. Some studies report individuals are enabled to walk for the first time in an aquatics environment; and if this form of exercise is repeated they have the opportunity to increase strength for a progression to on-land ambulation [3]. Swimming studies have documented improvements in muscle strengthening that improved postural stability for on-land locomotion (3 Kelly). Other research reports indicate an enhanced cardiorespiratory endurance, exercise capacity, and improved swim skills with aquatic exercise programming $[4,5]$ Fragala-Pinkham). Unfortunately recreational and fitness opportunities for children with disabilities are limited [6].

For the past two summers we have conducted an 8-week surf instruction program specifically designed for children with disabilities. IRB approval and informed consent is obtained prior to the program. This program runs during May and June and generally has between 15 and 25 children between the ages of 5-19 years. Our participants have been diagnosed with developmental, sensory and/or physical disabilities. The children had a wide range of disabilities including: intellectual, learning, Down syndrome, Dandy-Walker syndrome, heart defects, hypothyroidism and attention deficit disorder. Parents or guardians are required to be at the beach when their child participates. The program is known as the University of Rhode Island's Ocean Therapy program and it meets at a local Rhode Island beach, Narragansett Town Beach. The program has been staffed with physical education, exercise science, and physical therapy students and faculty in the Departments of Kinesiology and Physical Therapy, College of Human Science and Services, University of Rhode Island. Twice a week various sized surf boards and wet suits are delivered to the beach [7] and the children have one hour of surf instruction. The instructional goals are to teach each child to paddle, to balance on the board while in various positions, to catch a wave and ride it into shore and lastly to paddle back out through the surf. Each child has their own instructor who formulates individualized instructional goals designed around each child's physical and cognitive needs [8].

We fitness tested the children prior to and after the Ocean Therapy program using the 20 meter pacer test as well as a few measures of strength and flexibility [9]. Our pilot data indicated that the children significantly improved their cardiorespiratory endurance, core body strength, and some measures of flexibility. Our Rhode Island program joins others around the world that are using ocean surfing as a novel physiotherapy environment. These programs include Surfers Healing, Ride-a-Wave both in the United States, and Disabled Surfer's Association in Australia and Freedom Surf in the United Kingdom. They indicate that this novel physiotherapy environment can provide an environment for the disabled child or adult that can expand their rehabilitation, recreational, and fitness opportunities.

\section{References}

1. Denning WM, Bressel E, Dolny D, Bressel M, Seeley MK, et al. (2012)A review of biophysical differences between aquatic and land-based exercise. Intern $\mathrm{J}$ of Aquatic Res and Ed 6: 46-67.

2. Koury K (1996) Aquatic therapy programming. Human Kinetics press, Champaign.

3. Kelly M, Darrah J (2005) Aquatic exercise for children with cerebral palsy. Dev Med Child Neurol 47: 838-842.

4. Fragala-Pinkham M, Haley SM, O'Neil ME (2008) Group aquatic aerobic exercise for children with disabilities. Dev Med Child Neurol 50: 822-827.

5. Fragala-Pinkham M, O'Neil ME, Haley SM (2010) Summative evaluation of a pilot aquatic exercise program for children with disabilities. Disabil Health $\mathrm{J} 3$ : 162-170.

6. Murphy NA, Carbone PS (2008) American Academy of Pediatrics Council on Children With Disabilities Promoting the participation of children with disabilities in sports, recreation, and physical activities. Pediatrics 121: 1057-1061.

7. Lamont LS, Pangiotis P, Armitano C, Clapham E (2014) Development of a wet suit for children with Down syndrome. Int $\mathrm{J}$ of Aquatics Res and Ed 8: 98-104.

8. Clapham E, Armitano C, Lamont LS (in press) The ocean as a unique therapeutic environment: Developing a surfing program. J of Physical Education, Recreation, and Dance.

9. Short FX, Winnick JP (1999) The fitness challenge: Software for the Brockport physical fitness test [computer software] Human Kinetics, Champaign.

*Corresponding author: Linda S Lamont, Department of Kinesiology, College of Human Science and Services, University of Rhode Island, Kingston, USA, Tel: 352 236-1388; E-mail: lamont@mail.uri.edu

Received March 25, 2014; Accepted March 26, 2014; Published April 02, 2014

Citation: Lamont LS, Armitano C, Clapham E (2014) Ocean Surfing as a Novel Physiotherapy Environment: A Commentary. J Nov Physiother 4: e133 doi:10.4172/2165-7025.1000e133

Copyright: (c) 2014 Lamont LS, et al. This is an open-access article distributed under the terms of the Creative Commons Attribution License, which permits unrestricted use, distribution, and reproduction in any medium, provided the original author and source are credited. 